\title{
S100A10 and Cancer Hallmarks: Structure, Functions, and its Emerging Role in Ovarian Cancer
}

\author{
Tannith M. Noye ${ }^{1}$, Noor A. Lokman ${ }^{1}$, Martin K. Oehler ${ }^{1,2}$ and Carmela Ricciardelli ${ }^{1, *}$ (D) \\ 1 Discipline of Obstetrics and Gynaecology, Adelaide Medical School, Robinson Research Institute, \\ The University of Adelaide, Adelaide 5005, Australia; tannith.noye@adelaide.edu.au (T.M.N.); \\ noor.lokman@adelaide.edu.au (N.A.L.); martin.oehler@adelaide.edu.au (M.K.O.) \\ 2 Department of Gynaecological Oncology, Royal Adelaide Hospital, Adelaide 5000, Australia \\ * Correspondence: carmela.ricciardelli@adelaide.edu.au; Tel.: +61-0883138255
}

Received: 5 November 2018; Accepted: 17 December 2018; Published: 19 December 2018

\begin{abstract}
S100A10, which is also known as p11, is located in the plasma membrane and forms a heterotetramer with annexin A2. The heterotetramer, comprising of two subunits of annexin A2 and S100A10, activates the plasminogen activation pathway, which is involved in cellular repair of normal tissues. Increased expression of annexin A2 and S100A10 in cancer cells leads to increased levels of plasmin — which promotes the degradation of the extracellular matrix-increased angiogenesis, and the invasion of the surrounding organs. Although many studies have investigated the functional role of annexin A2 in cancer cells, including ovarian cancer, S100A10 has been less studied. We recently demonstrated that high stromal annexin A2 and high cytoplasmic S100A10 expression is associated with a 3.4-fold increased risk of progression and 7.9-fold risk of death in ovarian cancer patients. Other studies have linked S100A10 with multidrug resistance in ovarian cancer; however, no functional studies to date have been performed in ovarian cancer cells. This article reviews the current understanding of S100A10 function in cancer with a particular focus on ovarian cancer.
\end{abstract}

Keywords: S100A10; annexin A2; plasmin; ovarian cancer; chemotherapy resistance

\section{Introduction}

Ovarian cancer is the most lethal gynecological malignancy with a 5-year survival rate of only about 46\% [1]. It is estimated for 2018 that worldwide there will be about 295,414 new ovarian cancer cases and 184,799 women will die from this disease [2]. The poor survival rate can be attributed to the fact that ovarian cancer has non-specific symptoms and as a result is often diagnosed at stage 3 or 4 . High recurrence rates following treatment and subsequent chemotherapy resistance is another reason [3]. Epithelial ovarian cancers are the most common ovarian malignancies and of that $70 \%$ of the subtype are high-grade serous carcinomas. High-grade serous carcinomas have high chemosensitivity following initial treatment with platinum-based therapies, but $75 \%$ of patients will relapse and ultimately die from developing chemoresistant disease [4].

Chemotherapy resistance is one of the main reasons for the fatal outcome of ovarian cancer. Thus, discovering and understanding the underlying molecular mechanisms involved in drug resistance is crucial for identifying novel and effective therapeutic targets to be able to improve survival. Resistance mechanisms identified in ovarian cancer include genetic mutations, epigenetic changes, and dysfunctional DNA repair (reviewed in $[5,6]$ ). Other identified causes for chemotherapy resistance include upregulation of ATP-binding cassette $(\mathrm{ABC})$ transporters responsible for efflux of cancer therapies [7], activation of cancer stem cells, and epithelial to mesenchymal transition (EMT), as well as alterations to the tumor microenvironment $[8,9]$. 
Predicting the response to drug therapies remains a major challenge in ovarian cancer. Currently, there are no predictors of response to first-line chemotherapy in ovarian cancer, and after recurrence, the prediction of the response to second-line chemotherapy is determined empirically from the platinum-free interval (PFI) after the first treatment [4]. Recent studies have used a chemoresponse assay (CRA) to improve patient selection for different chemotherapy treatments [10-13]. Overall, these studies found that patients with assay-sensitive tissue had improved progression-free survival (PFS) compared to patients with non-sensitive tissue. The inclusion of additional biomarkers that can predict chemotherapy response together with CRAs would enable more effective, individualized patient management and importantly would spare patients from the side effects of ineffective drugs.

Recent studies have linked S100A10 with chemotherapy resistance and poor prognosis in serous ovarian cancer [14-16]; however, no functional studies have been performed to date. The aims of this review are to highlight the current understanding of S100A10 function in cancer cells-with a particular focus on ovarian cancer-and to discuss the potential for using S100A10 as a predictive marker and targeting S100A10 to inhibit cancer progression and treatment resistance.

\section{S100A10 Structure and Function}

S100A10, which is also known as p11 or annexin A2 light chain, belongs to the calcium-binding S100 family, which is characterized by EF-hand calcium-binding motifs [17-19]. To date, at least 25 S100 proteins have been identified; the majority are clustered at the chromosome locus 1q21, which is prone to genomic alterations [18]. S100 protein interacts with multiple other proteins and exerts a broad range of cellular functions including (i) phosphorylation; (ii) maintaining cell shape and motility; (iii) calcium homeostasis; (iv) enzyme activity modulation; and (v) transduction pathway signaling [20]. S100 proteins can form both homodimeric and heterodimeric complexes with each other and undergo a conformation change following calcium binding [17]. S100A10 monomers contain four $\alpha$ helical domains (H-I-H-IV) (Figure 1) and are unique from other S100 protein family members as its EF-hands cannot bind to calcium [21]. S100A10 adopts a permanently open conformation comparable to the calcium-bound conformation observed with the other S100 proteins [21]. S100A10 is expressed ubiquitously in the majority of cells and plays a major role in fibrinolysis, wound healing, and angiogenesis [22,23]. Recent studies have shown that S100A10 is important in regulating other physiological processes, including immune cell function [24,25], reproduction [26-28], neural cell function [29,30], and heart function [31].

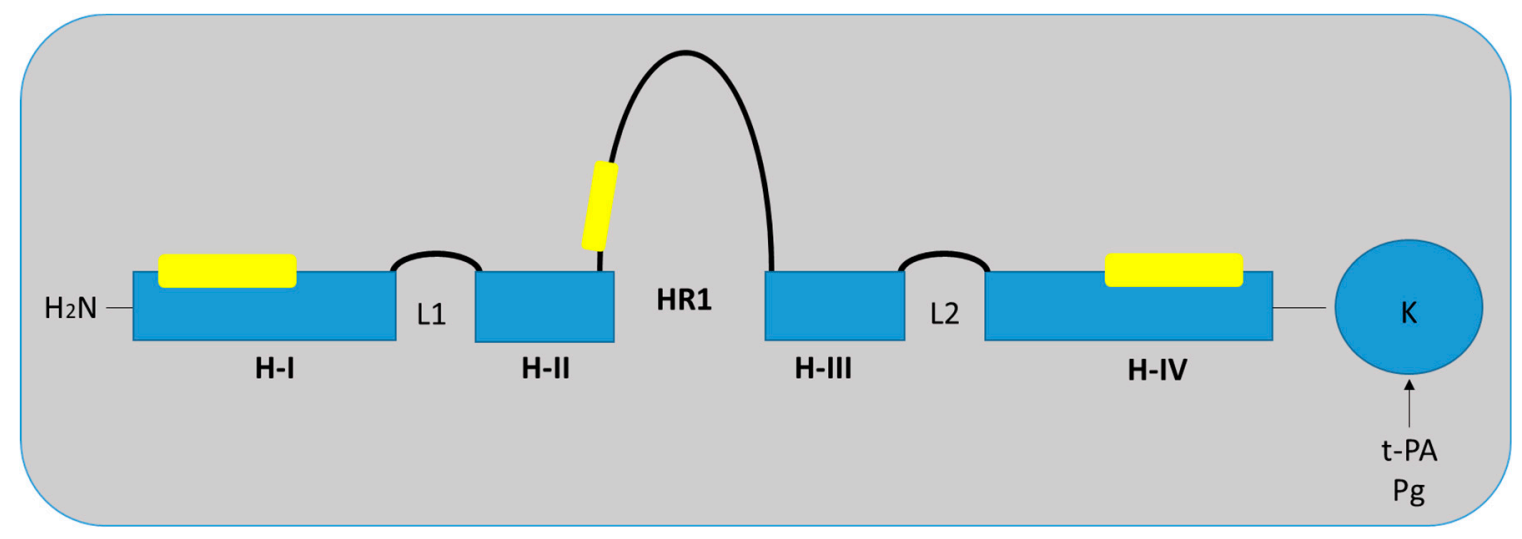

Figure 1. Structure of S100A10 monomer. Each monomer contains four $\alpha$ helical domains H-I, H-II, $\mathrm{H}-\mathrm{III}$, and H-IV. Two helical loops L1 and L2 separate H-I and H-II, and H-III and H-1V, respectively. A flexible linker or hinge region (HR1) is also located between H-II and H-III. Binding sites to annexin A2 are located in H-I, HR1, and H-IV, as indicated by the yellow boxes. S100A10 binds both tissue-type plasminogen activator (t-PA) and plasminogen (Pg) via the carboxyl-terminal lysine. Adapted from [32]. 


\section{S100A10 Interaction with Annexin A2}

S100A10 is a plasminogen receptor and binds to the cell membrane via its cell surface receptor, annexin A2 [32,33]. Annexin A2 is a soluble monomer in the cytoplasm, and when annexin A2 is sufficiently expressed, it binds to S100A10, forming a stable heterotetramer. Annexin A2 is phosphorylated for conformation changes to occur and translocates the heterotetramer to the cell surface [34]. S100A10 binding to plasminogen results in the activation of plasminogen activators-tissue-type plasminogen activator (t-PA) and urokinase-type plasminogen activator (uPA) —and the conversion of plasminogen to plasmin (reviewed in [32]). S100A10 interacts with annexin A2 to form a heterotetramer, also known as AIIt, which consists of two subunits of annexin A2 and two subunits of S100A10 [35,36]. AIIt activates the plasminogen activation pathway to increase plasmin production in various types of cells [32,37]. Normal endothelial cells utilize S100A10 in the plasminogen activation pathway, converting plasminogen to plasmin, which is vital for fibrinolysis and angiogenesis [22,32]. S100A10 has been shown to regulate up to $90 \%$ of plasmin produced in endothelial cells [32]. Plasmin can then degrade fibrin and activate matrix metalloproteinases (MMPs), which in turn promotes degradation of the extracellular matrix (ECM) [38]. S100A10-null mice have been shown to exhibit increased fibrin accumulation [22]. Endothelial cells from S100A10-null mice show a $40 \%$ reduction in plasminogen binding and plasmin generation in vitro compared with wild-type mice and exhibit defective angiogenesis [22].

Binding of S100A10 occurs at the annexin A2 N-terminus [39]. This interaction with the annexin A2 N-terminus is required for binding since the removal of this binding leads to the loss of the interaction with S100A10 and results in reduced plasmin production [40]. Several groups have reported that annexin A2 is required to transport S100A10 to the cell surface, which is dependent on the phosphorylation of annexin A2 [34,41-43]. S100A10 levels on the cell surface can also be regulated by IFN- $\gamma$ involving annexin A2 via an exosomal secretion pathway [44]. Although earlier studies reported that annexin A2 is a plasminogen receptor [45], more recent studies support that S100A10 rather than annexin $\mathrm{A} 2$ is the major plasminogen receptor [46]. It has been proposed that annexin $\mathrm{A} 2$ in the heterotetramer plays a role in stabilizing the S100A10 protein and localizing S100A10 to the cell surface. The interaction between S100A10 and annexin A2 is, therefore, thought to protect S100A10 from degradation by the proteasome $[21,46,47]$.

In cancer cells, increased annexin A2 and S100A10 expression result in increased plasmin production, which leads to the degradation of the ECM and activation of MMPs, thereby enabling the invasion of surrounding organs or local vasculature (Figure 2) [35-37]. Several studies have suggested that the knockdown of annexin A2 concurrently results in the loss of S100A10 [32,48-51]. Similarly, the loss of S100A10 has been shown to affect both the mRNA and protein levels of annexin A2 [23]. Therefore, it is not known whether the effects observed in many of these studies were mediated by annexin A2 or S100A10. It is likely that both proteins play reciprocal roles in mediating their function in cancer cells. 


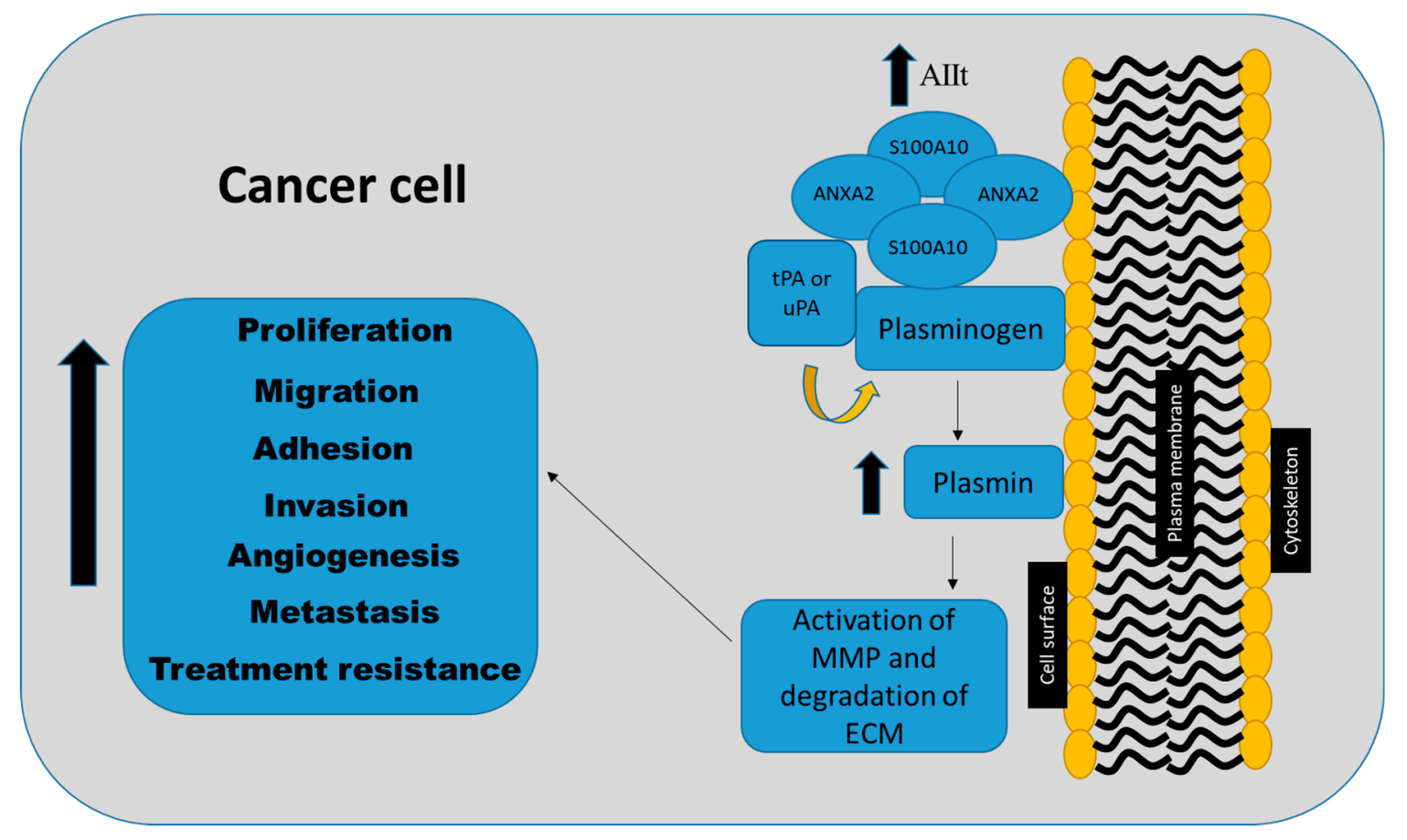

Figure 2. S100A10 plays a key role in regulating pro-tumorigenic processes including proliferation, adhesion, motility, invasion, metastasis, and therapy resistance. The S100A10-annexin A2 heterotetramer (AIIt) acts through the plasminogen activation pathway. AIIt on the cell surface of the plasma membrane activates plasminogen via tissue-type plasminogen activator ( $\mathrm{t}-\mathrm{PA}$ ) and urokinase-type plasminogen activator (uPA) and increases the production of plasmin, leading subsequently to the activation of metalloproteinases (MMPs) and the degradation of the extracellular matrix $(\mathrm{ECM})$ proteins, which promote tumor progression and treatment resistance.

\section{Interaction of S100A10 with Other Proteins}

In addition to binding annexin A2, S100A10 plays a role in the trafficking of other membrane proteins including sodium channel protein Nav 1.8 [52], potassium channel protein TASK-1 [53], channel proteins TRPV5 and TRPV6 [54], the acid-sensing ion channel ASIC1a [55], and serotonin 5-HT1B receptor [56]. S100A10 is, therefore, thought to play an important role in cell surface presentation of other plasma membrane proteins in addition to annexin A2 [17]. S100A10 functionally acts as a linking protein with the ability to bind transmembrane proteins, thereby aiding the transportation of proteins to the plasma membrane [17]. Protein crystallography has also shown that AIIt interacts with AHNAK, a protein involved in wound repair [57,58], and ARCA3, which is involved in chromatin remodeling [59]. More recent studies have also shown that S100A10 is required for the organization of actin stress fibers and the formation of focal adhesions by HeLa cells via Rac1 signaling [60]. The depletion of S100A10 led to the disruption of stress fiber formation and suppression of Rac1 activation [60].

\section{S100A10 Expression in Cancers}

The expression of S100A10 in cancer has been widely studied and is summarized in Table 1. The role of S100A10 in cancer was first identified in acute promyelocytic leukemia (APL), a subtype characterized by the expression of a fusion protein formed by the fusion of retinoic acid receptor alpha with promyelocytic leukemia (PML-RAR $\alpha$ ) genes [61]. Patients with APL experience severe bleeding that results from increased plasmin production [61,62]. Increased plasmin levels are due to the upregulation of both annexin A2 and S100A10 in APL cells due to the PML-RAR $\alpha$ oncoprotein $[46,63]$. S100A10 mRNA and protein expression are also upregulated in patients with acute lymphoblastic leukemia (ALL) [64]. S100A10 expression is increased in many other cancers [65-70] and is generally 
associated with a poor prognosis (Table 1). In kidney cancers, S100A10 expression is 2.5-fold higher than in normal kidney tissue [71]. Non-cancerous resections adjacent to kidney tumors show no expression of S100A10; however, S100A10 is expressed in renal cell carcinoma lesions [72]. S100A10 expression is increased in melanoma in comparison to levels in normal skin [69]. The expression of S100A10 is also upregulated in basal-type breast cancers [70]. S100A10 is overexpressed in gastric cancers [65,73], precancerous lesions in the stomach [67], and high S100A10 expression is associated with gastric cancer metastasis to the lymph nodes [67]. Overexpression of S100A10 has also been observed in anaplastic large cell lymphoma [68]. However, reduced S100A10 expression has also been reported in prostate cancer [74] and thyroid carcinoma [75]. Chetcuti et al. reported S100A10 mRNA expression in prostate cancer tissues but surprisingly found that S100A10 protein is not expressed [74], signifying potential post-translational modifications. S100A10 protein is present in the normal follicular thyroid tissues, but S100A10 expression is reduced in follicular adenoma and follicular thyroid carcinomas [75]. However, increased levels of S100A10 are present in all anaplastic thyroid carcinomas, which is the most aggressive form of thyroid malignancy, suggesting that S100A10 plays a role in the progression of thyroid carcinomas [76]. Tan et al. reported that high cytoplasmic S100A10 expression in advanced stage gallbladder carcinoma is associated with poor prognosis [77]. Overexpression of S100A10 is also associated with poor prognosis in lung carcinoma $[78,79]$ and pancreatic cancer [80]. A recent study identified S100A10 as one of a three-gene expression signature to independently predict survival of lung adenocarcinoma patients [81]. Similarly, in colorectal carcinomas, increased S100A10 protein is associated with a poor prognosis and reduced overall survival (OS) [82]. Increased S100A10 expression is independently associated with recurrence in colorectal cancer patients [83].

Table 1. S100A10 gene and protein expression in cancers.

\begin{tabular}{|c|c|c|}
\hline Cancer & S100A10 Expression & Ref. \\
\hline Blood & $\begin{array}{l}\text { S100A10 expression is increased on the surface of leukemia cells } \\
\text { S100A10 mRNA and protein is upregulated in B-cell acute lymphoblastic leukemia }\end{array}$ & $\begin{array}{c}{[46,63]} \\
{[64]}\end{array}$ \\
\hline Breast & S100A10 expression is upregulated in basal-type breast cancer & [70] \\
\hline Colorectal & $\begin{array}{l}\text { S100A10 is increased in hereditary polyposis colorectal cancer } \\
\text { Increased S100A10 expression is associated with poor prognosis and reduced overall survival in colorectal } \\
\text { cancer }\end{array}$ & $\begin{array}{l}66] \\
{[82]} \\
{[83]}\end{array}$ \\
\hline Gallbladder & High cytoplasmic S100A10 expression is associated with poor prognosis & [77] \\
\hline Kidney & $\begin{array}{l}\text { S100A10 expression is } 2.5 \text {-fold higher in renal cell carcinoma compared with normal kidney tissue } \\
\text { S100A10 is expressed in renal cell carcinoma and absent in non-cancerous renal tumors }\end{array}$ & {$[71]$} \\
\hline Lung & Overexpression of S100A10 is associated with poor prognosis & {$[78,79,84]$} \\
\hline Lymphatic & S100A10 is overexpressed in anaplastic large cell lymphoma & [68] \\
\hline Pancreas & S100A10 mRNA and protein is overexpressed in pancreatic cancer and predicts patient outcome & [80] \\
\hline Prostate & S100A10 expression is lost in prostate cancer tissues & [74] \\
\hline Skin & S100A10 expression is increased in melanoma compared with normal skin & [69] \\
\hline Stomach & $\begin{array}{l}\text { S100A10 is overexpressed in gastric cancer } \\
\text { S100A10 expression is upregulated in pre-cancerous lesions and associated with gastric cancer metastasis to } \\
\text { the lymph node }\end{array}$ & $\begin{array}{c}{[65,73]} \\
{[67]}\end{array}$ \\
\hline Thyroid & $\begin{array}{l}\text { S100A10 is overexpressed in anaplastic thyroid carcinomas compared with normal tissues } \\
\text { S100A10 expression is decreased in follicular adenomas and thyroid carcinomas }\end{array}$ & $\begin{array}{l}{[76]} \\
{[75]}\end{array}$ \\
\hline
\end{tabular}

\section{Functional Role of S100A10 in Cancer}

S100A10 plays a pro-tumorigenic role by regulating proliferation, cell adhesion, migration, invasion, metastasis, and therapy resistance in various malignancies (summarized in Table 2 and Figure 2). Collectively, these studies establish a pro-tumorigenic role for S100A10 as a key contributor in plasmin regulation, tumor progression, and metastasis. 
Table 2. The functional roles of S100A10 in cancer cells.

\begin{tabular}{|c|c|c|}
\hline Function & Observation & Ref. \\
\hline \multirow{7}{*}{ Proliferation } & $\begin{array}{l}\text { S100A10 is upregulated by p53 activation in breast cancer cells } \\
\text { Lewis Lung carcinoma and T241 fibrosarcoma proliferation is inhibited in S100A10 knockout mice }\end{array}$ & {$[85]$} \\
\hline & $\begin{array}{c}\text { S100A10 is downregulated by a knockdown of annexin A2, which decreases the proliferation of breast } \\
\text { cancer cell lines }\end{array}$ & [50] \\
\hline & & [87] \\
\hline & \multirow{2}{*}{$\begin{array}{l}\text { formation and growth of lung cancer cells } \\
\text { Cell growth inhibition by the microRNA miR-590-5P in hepatic carcinoma cells is mediated via S100A10 } \\
\text { Annexin A2/S100A10 activates the ERK1/2 and AKT pathways in multiple myeloma cells to enhance } \\
\text { cell growth }\end{array}$} & [88] \\
\hline & & [89] \\
\hline & \multirow{2}{*}{$\begin{array}{l}\text { S100A10 knockdown reduces proliferation of colon cancer cells } \\
\text { S100A10 knockdown inhibits growth of pancreatic cancer cells PANC-1 in immunocompromised } \\
\text { NOD/SCID mice }\end{array}$} & [82] \\
\hline & & [80] \\
\hline \multirow[b]{2}{*}{ Adhesion } & Annexin A2/S100A10 regulates adhesion of leukemia cells and prostate cancer cells to osteoblasts & {$[64,90]$} \\
\hline & $\begin{array}{l}\text { Cell surface S100A10 expression promotes adhesion of breast and prostate cancer cells to endothelial cells } \\
\text { in vitro }\end{array}$ & {$[90,91]$} \\
\hline \multirow{3}{*}{ Migration } & S100A10 expression is associated with the recruitment and migration of macrophages & {$[24,70,86]$} \\
\hline & $\begin{array}{l}\text { The displacement of S100A10 from annexin A2 attenuates plasminogen activation and impairs the } \\
\text { migration of A549 lung cancer cells }\end{array}$ & [87] \\
\hline & S100A10 knockdown reduces the migration of colon cancer cells & [82] \\
\hline \multirow{7}{*}{ Invasion } & S100A10 in colon cancer cells is crucial for promoting plasmin production and cell invasiveness & [92] \\
\hline & S100A10 antibodies inhibit the invasion of acute promyelocytic leukemia cells & [63] \\
\hline & S100A10 expression in fibrosarcoma cells increases plasmin production and cell invasiveness & [93] \\
\hline & $\begin{array}{l}\text { The displacement of S100A10 from annexin A2 attenuates plasminogen activation and impairs invasion } \\
\text { of lung cancer cells }\end{array}$ & [87] \\
\hline & Macrophages from S100A10 knockout mice have reduced plasmin-dependent invasion & [24] \\
\hline & $\begin{array}{l}\text { S100A10 depletion in RAS-transformed cell lines (HEK293, NIH-3T3) results in a loss of plasmin } \\
\text { production and reduced cell invasiveness }\end{array}$ & [94] \\
\hline & siRNA S100A10 reduces invasion of HCT-116 and DLD-1 colon cancer cell lines & [82] \\
\hline Angiogenesis & S100A10-null mice have reduced blood vessel density compared to wild-type mice & [86] \\
\hline \multirow{3}{*}{ Metastasis } & Loss of S100A10 reduces metastatic burden in the HT1080 fibrosarcoma mouse model & [93] \\
\hline & Overexpression of S100A10 increases the metastatic burden in the HT1080 fibrosarcoma mouse model & [93] \\
\hline & S100A10 is one of 170 genes activated during the process of intravasation in breast cancer cells & [95] \\
\hline \multirow{4}{*}{ Treatment resistance } & Disruption of both annexin A2 and S100A10 interactions sensitize leukemia cells to chemotherapy & [64] \\
\hline & Overexpression of S100A10 reduces the sensitivity of colorectal cancer cells to oxaliplatin & [51] \\
\hline & $\begin{array}{c}\text { Knockdown of S100A10 inhibits annexin A2 phosphorylation and increases sensitivity of acute } \\
\text { lymphoblastic leukemia cells to prednisolone }\end{array}$ & [96] \\
\hline & $\begin{array}{l}\text { S100A10 protein expression is increased in tamoxifen-resistant MCF-7 breast cancer cells and breast } \\
\text { cancer tissues }\end{array}$ & {$[97,98]$} \\
\hline
\end{tabular}

\subsection{Proliferation}

S100A10 has been linked to play a key role in proliferation in many different types of cancers. Increased cell proliferation of basal-type breast cancer cells is associated with upregulation of S100A10 expression [70]. The knockdown of annexin A2 and concurrent loss of S100A10 expression decreases the cell proliferation of invasive MDA-MB-435S breast cancer cells [50]. The growth of Lewis Lung carcinoma (LLC) and T241 fibrosarcomas is greatly reduced in S100A10 knockout mice compared with wild-type mice [86]. The displacement of S100A10 from annexin A2 attenuates plasminogen activation, impairing colony formation and growth of A549 lung cancer cells [87]. S100A10 has also been shown to bind to Bcl-2-associated death promoter (BAD) protein and adversely affects BAD-induced apoptosis in Chinese hamster ovary (CHO) cells [99]. S100A10 is upregulated by p53 activation, which regulates pro-survival functions in MCF-7 breast cancer cells [85]. Inhibition of hepatic carcinoma, HepG2 cell growth by the microRNA, miR-590-5P is mediated via S100A10 expression [88]. Together annexin A2/S100A10 has also been shown to activate the ERK1/2 and AKT pathways in MM.1S multiple myeloma cells to enhance cell growth [89]. Knockdown of S100A10 by siRNA significantly reduces the proliferation of both HCT-116 and DLD-1 colon cancer cells [82]. A more recent study found that knockdown of S100A10 inhibits the growth of pancreatic cancer cells PANC-1 in immunocompromised NOD/SCID mice [80]. 


\subsection{Adhesion}

Adhesion of cancer cells is an important phase in the progression of disease. Myrvang and coworkers (2013) were able to show that cell surface S100A10 promotes the adhesion of breast cancer cells to endothelial cells in vitro [91]. S100A10 together with annexin A2 has been shown to regulate the adhesion of leukemia cells [64] and prostate cancer cells to osteoblasts [90]. These findings suggest that S100A10 and annexin A2 may aid the metastatic process by allowing cancer cells to reach the bone marrow.

\subsection{Migration}

S100A10 plays a role in promoting the migration of cancer cells. S100A10 expression promotes the migration of non-small cell lung cancer (NSCLC) A549 cancer cells in vitro [87]. Knockdown of S100A10 by siRNA significantly reduces the migration capacity of two colorectal cancer cell lines, HCT-116 and DLD-1 [82]. Several studies also suggest a direct link between S100A10 expression with the recruitment and migration of macrophages $[24,70,86]$. S100A10 also plays a critical role in the migration of macrophages to tumor sites and is reported to be a rate-limiting step that controls tumor progression [86].

\subsection{Invasion}

Several studies have shown that S100A10 plays a role in promoting the invasion of cancer cells. Transfection of human HT1080 fibrosarcoma cells with S100A10 antisense oligonucleotides result in a loss of S100A10 protein from the cell surface, decreased plasmin production, and reduced cell invasion [93]. Knockdown of S100A10 by siRNA significantly reduces the invasion capacity of HCT-116 and DLD-1 colorectal cancer cell lines [82]. S100A10 alone in the absence of annexin A2 is crucial for promoting plasmin production and the invasiveness of CCL-22 colorectal cancer cells [92]. A study by Phipps et al. (2011) has also demonstrated that LLC and T241 cells are unable to grow and invade in S100A10-null mice due to the inability to recruit macrophages to the tumor site [86]. The macrophages from S100A10 knockout mice exhibit reduced plasmin-dependent invasion [24]. The displacement of S100A10 from annexin A2 by DLC1, a Rho GTPase-activating protein (RhoGAP) that functions as a tumor suppressor, results in the attenuation of plasminogen activation and impaired invasion of A549 lung cancer cells [87]. The depletion of S100A10 in the kidney (HEK293) and fibroblast (NIH-3T3) cell lines also result in the loss of plasmin production and reduced cell invasiveness [94]. Moreover, a recent study has shown that U937/PR9 and NB4 leukemic cell invasion can be blocked by either annexin A2 or S100A10 antibodies in vitro [63].

\subsection{Angiogenesis}

The process of forming new blood vessels also depends on the presence of S100A10 [86]. Phipps et al. (2011) showed using the S100A10-null mouse model that the density of blood vessels is decreased by over 50\% compared with wild-type [86]. S100A10-null macrophages are not able to stimulate angiogenesis and LLC tumor growth in the S100A10-null mice.

\subsection{Metastasis}

As the hallmark of disease progression, metastasis has been shown to be promoted by the presence of S100A10. S100A10 plays an important role in this process, as overexpression of S100A10 in HT1080 fibrosarcoma was shown to increase the lung metastatic burden in mice by 16 -fold while the loss of S100A10 reduced the metastatic burden by 3-fold [93]. A more recent study analyzing circulating tumor cells from breast cancer patients reported that $S 100 A 10$ is one of the 170 genes activated during intravasation, an important process in the initial stages of metastasis [95]. 


\subsection{Therapy Resistance}

Increased S100A10 has also been linked to therapy resistance. Treatment with small molecules that inhibit the S100A10-annexin A2 interaction, antibodies against annexin A2 and S100A10, or the knockdown of S100A10 could all increase the sensitivity of NTPL-20 leukemia cells to the chemotherapy drug vincristine [64]. Spijkers-Hagelstein et al. (2013) were able to show that to improve the treatment success of glucocorticoid therapy in ALL, phosphorylation of annexin A2 is required; additionally, this phosphorylation requires S100A10 expression and the absence of both annexin A2 and S100A10 reduces the resistance to treatment in the ALL SEM cell line [96]. COLO-320 colorectal cancer cells that overexpress S100A10 also show reduced sensitivity to oxaplatin [51]. Increased S100A10 has been associated with tamoxifen resistance in MCF-7 breast cancer cells [97] and breast cancer tissues [98]. The mechanisms whereby S100A10 regulates therapy resistance is poorly understood and requires further investigation.

\section{Role of S100A10 in Ovarian Cancer and Chemotherapy Resistance}

To date, there have been only three studies that have investigated the expression of S100A10 in ovarian cancer. The study by Gillet et al. (2012), which included 80 serous ovarian cancer patients treated with carboplatin and paclitaxel, found S100A10 to be one of the 11 signature genes whose expression is involved in multidrug resistance [100]. Another study by Nymoen et al. (2015) found that S100A10 protein expression in ovarian cancer tissues is related to poor chemotherapy response and associated with shorter overall and progression-free survival [15]. In the third study, Lokman et al. (2016) used 13 publicly available ovarian cancer microarray datasets including 722 serous ovarian cancer patients who had received single platinum treatment and 468 patients with combined platinum-taxane treatment [16]. They showed that high mRNA levels of S100A10 predict reduced OS and that high cytoplasmic S100A10 expression is significantly associated with reduced OS in serous ovarian cancer patients [16]. Moreover, high stromal annexin A2 and high cytoplasmic S100A10 expression in serous ovarian cancer tissues are associated with a 3.4-fold increased risk of progression and a 7.9-fold risk of ovarian cancer death [16]. Our preliminary studies investigating the mechanisms of chemotherapy resistance in ovarian cancer have shown increased S100A10 expression in chemotherapy-resistant disease compared to expression observed in the same patient tissue at diagnosis (Figure 3). Together these findings suggest that S100A10 plays an important role in the progression of serous ovarian cancer and chemotherapy resistance. Future studies are required to investigate further the functional role of S100A10 in ovarian cancer, its usefulness in predicting chemotherapy response, and as a therapeutic target to overcome chemoresistance.
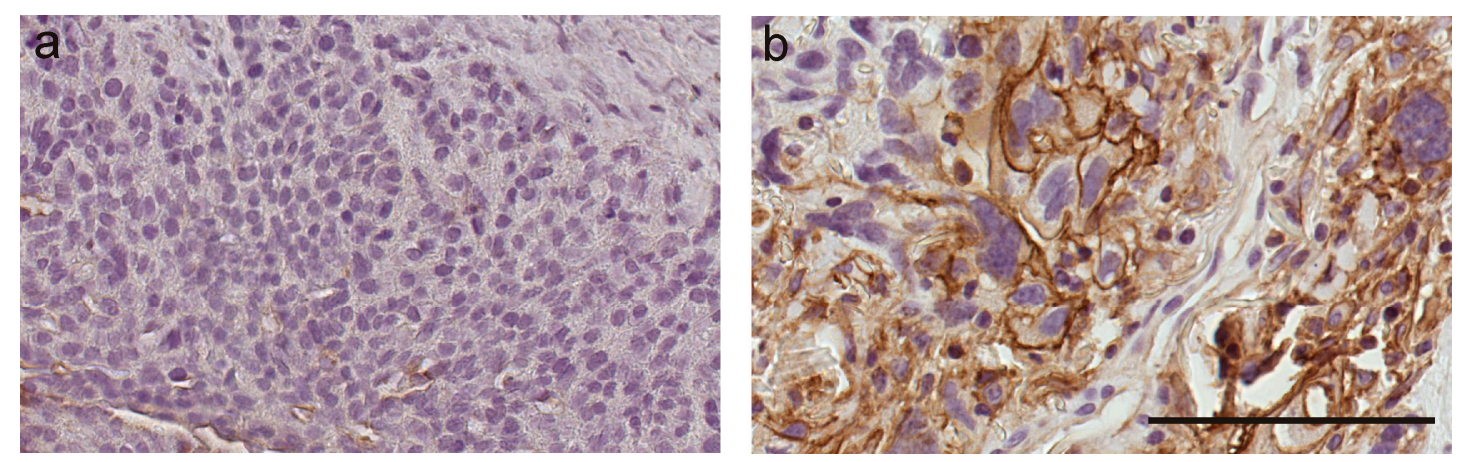

Figure 3. S100A10 immunostaining in matching tissues from a serous ovarian cancer patient at diagnosis (a) and recurrence with chemotherapy-resistant disease (b). S100A10 expression is increased in tumor tissue at relapse with chemotherapy-resistant disease compared to tumor tissue at diagnosis. S100A10 antibody using citrate buffer retrieval (1/1000, BD Biosciences) [16]. Scale bar $=100 \mu \mathrm{m}$. 


\section{Strategies to Target S100A10 in Cancer Cells}

Different therapeutic strategies have been used to target S100A10 including annexin A2 peptides, S100A10 neutralizing antibodies, small molecule inhibitors, and the vitamin A metabolite all-trans retinoic acid (ATRA). An annexin A2 peptide containing the S100A10 binding site prevents the binding of prostate cancer cells [90] and multiple myeloma cells to osteoblasts [89]. S100A10 antibodies are effective in reducing leukemia cell invasion in vitro [63] and homing of leukemia cells to the bone marrow in vivo [64]. Current studies in our laboratory are investigating the ability of S100A10 antibodies to block serous ovarian cancer motility and invasion.

Using both, a receptor-guided and ligand-guided virtual screening approach has led to the identification of a number of small molecules that inhibit the interaction between annexin A2 and S100A10 [101-104]. One of these inhibitors 5-benzyl-4-methyl-2-(toluene-4-sulfonylamino)-thiophene-3-carboxylic acid amide that could block the interaction between annexin A2 and S100A10 has recently been shown to inhibit the adhesion of leukemic cells to osteoblasts in vivo and increase the sensitivity of leukemic cells to drugs such as dexamethasone and vincristine in vitro [64]. Further in vitro and in vivo studies are required to determine the effectiveness of these small molecule inhibitors in blocking pro-tumorigenic behavior in a wide range of cancer cells, including ovarian cancer.

ATRA is currently used as a primary treatment for patients with APL $[61,62,105]$. ATRA has been shown to be beneficial in inducing differentiation and promoting apoptosis of leukemic cells and improving bleeding symptoms by inhibiting plasmin production and decreasing annexin A2 and S100A10 expression [46,106-108]. Treatment of APL leukemic cell lines with ATRA causes the rapid loss of both cell surface annexin A2 and S100A10 protein $[46,63,109]$. Gladwin et al. (2000) also showed that ATRA reduces S100A10 protein levels but not S100A10 mRNA levels in bronchial epithelial cells (BEAS-2B) [110]. These findings suggest that ATRA exerts its effects to inhibit S100A10 protein levels via a post-translational mechanism. Recent studies further investigating the mechanism whereby ATRA inhibits S100A10 protein levels suggest that ATRA promotes the proteasomal degradation of S100A10 in a ubiquitin-independent manner [111]. ATRA treatment in MCF-7 breast cancer cells reduce S100A10 but not annexin A2 transcript and protein levels, indicating that ATRA can regulate S100A10 levels independently of PML/RAR $\alpha$ and annexin A2 [111]. While the effects of ATRA on ovarian cancer cell proliferation and apoptosis have been previously investigated [112], to date no data has been reported on the effects of ATRA on both annexin A2 and S100A10 expression in ovarian cancer cells. Ongoing studies in our laboratory are investigating the ability of ATRA to inhibit cell proliferation and S100A10 expression in a range of serous ovarian cancer cell lines and serous ovarian cancer tissues using an ex-vivo explant assay [113].

A potential risk of using anti-S100A10 or anti-annexin A2 therapies is the increased risk of thromboembolic events. Previous studies have found increased thrombosis in patients receiving ATRA $[114,115]$ while in other studies the incidence of thrombosis was reported to be lower $[116,117]$. It will be important to monitor patients treated with anti-S100A10 therapies and consider antithrombotic prophylaxis if they have a high risk of thromboembolic events [118].

\section{Summary and Conclusions}

In conclusion, S100A10 has been shown to play an important role in promoting pro-tumorigenic behavior in many cancers. Emerging evidence shows an important role of the AIIt heterotetramer in the plasminogen activator system in cancer cells and a key role in macrophage migration. The interaction between annexin A2, S100A10, and t-PA mediates the conversion of plasminogen to plasmin, which facilitates the ECM degradation, MMP activation, and angiogenesis, leading to increased cancer cell migration, invasion, and metastasis. S100A10 also plays a significant role in the development of treatment resistance; however, the mechanisms involved are poorly understood and warrant further investigation. A greater understanding of the functional role of S100A10 in ovarian cancer cells could lead to the development of effective strategies to target S100A10 and annexin A2, inhibit progression, and overcome chemotherapy resistance in ovarian cancer patients. 
Author Contributions: Conceptualization, T.M.N, C.R. and N.A.L.; writing-original draft preparation, T.M.N.; writing-review and editing, T.M.N., C.R., N.A.L and M.K.O.

Funding: This research received no external funding.

Conflicts of Interest: The authors declare no conflict of interest.

\section{Abbreviations}

$\begin{array}{ll}\text { AIIt } & \text { S100A10-annexin A2 heterotetramer } \\ \text { ALL } & \text { acute lymphoblastic leukemia } \\ \text { APL } & \text { acute promyelotic leukemia } \\ \text { ABC } & \text { ATP-binding cassette } \\ \text { ATRA } & \text { all-trans retinoic acid } \\ \text { BAD } & \text { Bcl-2-associated death promoter } \\ \text { BEAS-2B } & \text { bronchial epithelial cells } \\ \text { CHO } & \text { Chinese hamster ovary } \\ \text { CRA } & \text { Chemoresponse assay } \\ \text { DLCI } & \text { data-link connection identifier } \\ \text { ECM } & \text { extracellular matrix } \\ \text { LLC } & \text { Lewis Lung Carcinoma } \\ \text { MMP } & \text { matrix metalloproteinases } \\ \text { NSCLC } & \text { non-small cell lung cancer } \\ \text { PFI } & \text { platinum-free interval } \\ \text { PFS } & \text { progression-free survival } \\ \text { Pg } & \text { plasminogen } \\ \text { PML } & \text { promyelocytic leukemia } \\ \text { OS } & \text { overall survival } \\ \text { RhoGAP } & \text { Rho GTPase-activating protein } \\ \text { t-PA } & \text { tissue-type plasminogen activator } \\ \text { uPA } & \text { urokinase-type plasminogen activator }\end{array}$

\section{References}

1. Miller, K.D.; Siegel, R.L.; Lin, C.C.; Mariotto, A.B.; Kramer, J.L.; Rowland, J.H.; Stein, K.D.; Alteri, R.; Jemal, A. Cancer treatment and survivorship statistics, 2016. CA Cancer J. Clin. 2016, 66, 271-289. [CrossRef] [PubMed]

2. Bray, F.; Ferlay, J.; Soerjomataram, I.; Siegel, R.L.; Torre, L.A.; Jemal, A. Global cancer statistics 2018: GLOBOCAN estimates of incidence and mortality worldwide for 36 cancers in 185 countries. CA Cancer J. Clin. 2018, 68, 394-424. [CrossRef] [PubMed]

3. Cannistra, S.A. Cancer of the ovary. N. Engl. J. Med. 2004, 351, 2519-2529. [CrossRef] [PubMed]

4. Colombo, P.E.; Fabbro, M.; Theillet, C.; Bibeau, F.; Rouanet, P.; Ray-Coquard, I. Sensitivity and resistance to treatment in the primary management of epithelial ovarian cancer. Crit. Rev. Oncol. Hematol. 2014, 89, 207-216. [CrossRef] [PubMed]

5. El Bairi, K.; Amrani, M.; Kandhro, A.H.; Afqir, S. Prediction of therapy response in ovarian cancer: Where are we now? Crit. Rev. Clin. Lab. Sci. 2017, 54, 233-266. [CrossRef] [PubMed]

6. van Zyl, B.; Tang, D.; Bowden, N.A. Biomarkers of platinum resistance in ovarian cancer: What can we use to improve treatment. Endocr. Relat. Cancer 2018, 25, R303-R318. [CrossRef] [PubMed]

7. Ween, M.P.; Armstrong, M.A.; Oehler, M.K.; Ricciardelli, C. The role of ABC transporters in ovarian cancer progression and chemoresistance. Crit. Rev. Oncol. Hematol. 2015, 96, 220-256. [CrossRef]

8. Helleman, J.; Jansen, M.P.; Burger, C.; van der Burg, M.E.; Berns, E.M. Integrated genomics of chemotherapy resistant ovarian cancer: A role for extracellular matrix, TGFbeta and regulating microRNAs. Int. J. Biochem. Cell Biol. 2010, 42, 25-30. [CrossRef]

9. Chien, J.; Kuang, R.; Landen, C.; Shridhar, V. Platinum-sensitive recurrence in ovarian cancer: The role of tumor microenvironment. Front. Oncol. 2013, 3, 251. [CrossRef] 
10. Rutherford, T.; Orr, J., Jr.; Grendys, E., Jr.; Edwards, R.; Krivak, T.C.; Holloway, R.; Moore, R.G.; Puls, L.; Tillmanns, T.; Schink, J.C.; et al. A prospective study evaluating the clinical relevance of a chemoresponse assay for treatment of patients with persistent or recurrent ovarian cancer. Gynecol. Oncol. 2013, 131, 362-367. [CrossRef]

11. Tian, C.; Sargent, D.J.; Krivak, T.C.; Powell, M.A.; Gabrin, M.J.; Brower, S.L.; Coleman, R.L. Evaluation of a chemoresponse assay as a predictive marker in the treatment of recurrent ovarian cancer: Further analysis of a prospective study. Br. J. Cancer 2014, 111, 843-850. [CrossRef] [PubMed]

12. Krivak, T.C.; Lele, S.; Richard, S.; Secord, A.A.; Leath, C.A., 3rd; Brower, S.L.; Tian, C.; Moore, R.G. A chemoresponse assay for prediction of platinum resistance in primary ovarian cancer. Am. J. Obstet. Gynecol. 2014, 211, 68.e1-68.e8. [CrossRef] [PubMed]

13. Plamadeala, V.; Kelley, J.L.; Chan, J.K.; Krivak, T.C.; Gabrin, M.J.; Brower, S.L.; Powell, M.A.; Rutherford, T.J.; Coleman, R.L. A cost-effectiveness analysis of a chemoresponse assay for treatment of patients with recurrent epithelial ovarian cancer. Gynecol. Oncol. 2015, 136, 94-98. [CrossRef] [PubMed]

14. Gillet, J.P.; Gottesman, M.M. Overcoming multidrug resistance in cancer: 35 years after the discovery of ABCB1. Drug Resist. Updat. 2012, 15, 2-4. [CrossRef] [PubMed]

15. Nymoen, D.A.; Hetland Falkenthal, T.E.; Holth, A.; Ow, G.S.; Ivshina, A.V.; Trope, C.G.; Kuznetsov, V.A.; Staff, A.C.; Davidson, B. Expression and clinical role of chemoresponse-associated genes in ovarian serous carcinoma. Gynecol. Oncol. 2015, 139, 30-39. [CrossRef] [PubMed]

16. Lokman, N.A.; Pyragius, C.E.; Ruszkiewicz, A.; Oehler, M.K.; Ricciardelli, C. Annexin A2 and S100A10 are independent predictors of serous ovarian cancer outcome. Transl. Res. 2016, 171, 83-95. [CrossRef] [PubMed]

17. Rescher, U.; Gerke, V. S100A10/p11: Family, friends and functions. Pflugers Arch. 2008, 455, 575-582. [CrossRef]

18. Chen, H.; Xu, C.; Jin, Q.; Liu, Z. S100 protein family in human cancer. Am. J. Cancer Res. 2014, 4, 89-115.

19. Bresnick, A.R.; Weber, D.J.; Zimmer, D.B. S100 proteins in cancer. Nat. Rev. Cancer 2015, 15, 96-109. [CrossRef]

20. Santamaria-Kisiel, L.; Rintala-Dempsey, A.C.; Shaw, G.S. Calcium-dependent and -independent interactions of the S100 protein family. Biochem. J. 2006, 396, 201-214. [CrossRef]

21. Liu, Y.; Myrvang, H.K.; Dekker, L.V. Annexin A2 complexes with S100 proteins: Structure, function and pharmacological manipulation. Br. J. Pharmacol. 2015, 172, 1664-1676. [CrossRef] [PubMed]

22. Surette, A.P.; Madureira, P.A.; Phipps, K.D.; Miller, V.A.; Svenningsson, P.; Waisman, D.M. Regulation of fibrinolysis by S100A10 in vivo. Blood 2011, 118, 3172-3181. [CrossRef] [PubMed]

23. Madureira, P.A.; Surette, A.P.; Phipps, K.D.; Taboski, M.A.; Miller, V.A.; Waisman, D.M. The role of the annexin A2 heterotetramer in vascular fibrinolysis. Blood 2011, 118, 4789-4797. [CrossRef] [PubMed]

24. O'Connell, P.A.; Surette, A.P.; Liwski, R.S.; Svenningsson, P.; Waisman, D.M. S100A10 regulates plasminogen-dependent macrophage invasion. Blood 2010, 116, 1136-1146. [CrossRef] [PubMed]

25. Hessner, F.; Dlugos, C.P.; Chehab, T.; Schaefer, C.; Homey, B.; Gerke, V.; Weide, T.; Pavenstadt, H.; Rescher, U. CC chemokine receptor 10 cell surface presentation in melanocytes is regulated by the novel interaction partner S100A10. Sci. Rep. 2016, 6, 22649. [CrossRef] [PubMed]

26. Bissonnette, L.; Drissennek, L.; Antoine, Y.; Tiers, L.; Hirtz, C.; Lehmann, S.; Perrochia, H.; Bissonnette, F.; Kadoch, I.J.; Haouzi, D.; et al. Human S100A10 plays a crucial role in the acquisition of the endometrial receptivity phenotype. Cell Adhes. Migr. 2016, 10, 282-298. [CrossRef] [PubMed]

27. Teijeiro, J.M.; Roldan, M.L.; Marini, P.E. Annexin A2 and S100A10 in the mammalian oviduct. Cell Tissue Res. 2016, 363, 567-577. [CrossRef] [PubMed]

28. Abd El-Aleem, S.A.; Dekker, L.V. Assessment of the cellular localisation of the annexin A2/S100A10 complex in human placenta. J. Mol. Histol. 2018, 49, 531-543. [CrossRef] [PubMed]

29. Svenningsson, P.; Kim, Y.; Warner-Schmidt, J.; Oh, Y.S.; Greengard, P. p11 and its role in depression and therapeutic responses to antidepressants. Nat. Rev. Neurosci. 2013, 14, 673-680. [CrossRef]

30. Lee, K.W.; Westin, L.; Kim, J.; Chang, J.C.; Oh, Y.S.; Amreen, B.; Gresack, J.; Flajolet, M.; Kim, D.; Aperia, A.; et al. Alteration by p11 of mGluR5 localization regulates depression-like behaviors. Mol. Psychiatry 2015, 20, 1546-1556. [CrossRef]

31. Meschin, P.; Demion, M.; Cazorla, O.; Finan, A.; Thireau, J.; Richard, S.; Lacampagne, A. p11 modulates calcium handling through 5-HT(4)R pathway in rat ventricular cardiomyocytes. Cell Calcium. 2015, 58, 549-557. [CrossRef] [PubMed] 
32. Madureira, P.A.; O'Connell, P.A.; Surette, A.P.; Miller, V.A.; Waisman, D.M. The biochemistry and regulation of S100A10: A multifunctional plasminogen receptor involved in oncogenesis. J. Biomed. Biotechnol. 2012, 2012, 353687. [CrossRef] [PubMed]

33. O'Connell, P.A.; Waisman, D.M. Regulation of plasmin generation by the annexin A2 heterotetramer: A shift in perspective. Future Oncol. 2012, 8, 763-765. [CrossRef] [PubMed]

34. Deora, A.B.; Kreitzer, G.; Jacovina, A.T.; Hajjar, K.A. An annexin 2 phosphorylation switch mediates p11-dependent translocation of annexin 2 to the cell surface. J. Biol. Chem. 2004, 279, 43411-43418. [CrossRef]

35. Lokman, N.A.; Ween, M.P.; Oehler, M.K.; Ricciardelli, C. The role of annexin A2 in tumorigenesis and cancer progression. Cancer Microenviron. 2011, 4, 199-208. [CrossRef] [PubMed]

36. Bharadwaj, A.; Bydoun, M.; Holloway, R.; Waisman, D. Annexin A2 heterotetramer: Structure and function. Int. J. Mol. Sci. 2013, 14, 6259-6305. [CrossRef]

37. Kumari, S.; Malla, R. New Insight on the Role of Plasminogen Receptor in Cancer Progression. Cancer Growth Metastasis 2015, 8, 35-42. [CrossRef] [PubMed]

38. Deryugina, E.I.; Quigley, J.P. Cell surface remodeling by plasmin: A new function for an old enzyme. J. Biomed. Biotechnol. 2012, 2012, 564259. [CrossRef]

39. Rety, S.; Sopkova, J.; Renouard, M.; Osterloh, D.; Gerke, V.; Tabaries, S.; Russo-Marie, F.; Lewit-Bentley, A. The crystal structure of a complex of p11 with the annexin II N-terminal peptide. Nat. Struct. Biol. 1999, 6, $89-95$.

40. Semov, A.; Moreno, M.J.; Onichtchenko, A.; Abulrob, A.; Ball, M.; Ekiel, I.; Pietrzynski, G.; Stanimirovic, D.; Alakhov, V. Metastasis-associated protein S100A4 induces angiogenesis through interaction with Annexin II and accelerated plasmin formation. J. Biol. Chem. 2005, 280, 20833-20841. [CrossRef]

41. He, K.L.; Deora, A.B.; Xiong, H.; Ling, Q.; Weksler, B.B.; Niesvizky, R.; Hajjar, K.A. Endothelial cell annexin A2 regulates polyubiquitination and degradation of its binding partner S100A10/p11. J. Biol. Chem. 2008, 283, 19192-19200. [CrossRef] [PubMed]

42. Valapala, M.; Vishwanatha, J.K. Lipid raft endocytosis and exosomal transport facilitate extracellular trafficking of annexin A2. J. Biol. Chem. 2011, 286, 30911-30925. [CrossRef] [PubMed]

43. Zheng, L.; Foley, K.; Huang, L.; Leubner, A.; Mo, G.; Olino, K.; Edil, B.H.; Mizuma, M.; Sharma, R.; Le, D.T.; et al. Tyrosine 23 phosphorylation-dependent cell-surface localization of annexin A2 is required for invasion and metastases of pancreatic cancer. PLoS ONE 2011, 6, e19390. [CrossRef] [PubMed]

44. Fang, Y.T.; Lin, C.F.; Wang, C.Y.; Anderson, R.; Lin, Y.S. Interferon-gamma stimulates p11-dependent surface expression of annexin A2 in lung epithelial cells to enhance phagocytosis. J. Cell Physiol. 2012, 227, 2775-2787. [CrossRef] [PubMed]

45. Hajjar, K.A.; Krishnan, S. Annexin II: A mediator of the plasmin/plasminogen activator system. Trends Cardiovasc. Med. 1999, 9, 128-138. [CrossRef]

46. O'Connell, P.A.; Madureira, P.A.; Berman, J.N.; Liwski, R.S.; Waisman, D.M. Regulation of S100A10 by the PML-RAR-alpha oncoprotein. Blood 2011, 117, 4095-4105. [CrossRef] [PubMed]

47. Bydoun, M.; Waisman, D.M. On the contribution of S100A10 and annexin A2 to plasminogen activation and oncogenesis: An enduring ambiguity. Future Oncol. 2014, 10, 2469-2479. [CrossRef]

48. Kwon, M.; MacLeod, T.J.; Zhang, Y.; Waisman, D.M. S100A10, annexin A2, and annexin a2 heterotetramer as candidate plasminogen receptors. Front. Biosci. 2005, 10, 300-325. [CrossRef]

49. Hou, Y.; Yang, L.; Mou, M.; Hou, Y.; Zhang, A.; Pan, N.; Qiang, R.; Wei, L.; Zhang, N. Annexin A2 regulates the levels of plasmin, S100A10 and Fascin in L5178Y cells. Cancer Investig. 2008, 26, 809-815. [CrossRef]

50. Zhang, J.; Guo, B.; Zhang, Y.; Cao, J.; Chen, T. Silencing of the annexin II gene down-regulates the levels of S100A10, c-Myc, and plasmin and inhibits breast cancer cell proliferation and invasion. Saudi Med. J. 2010, 31, 374-381.

51. Suzuki, S.; Tanigawara, Y. Forced expression of S100A10 reduces sensitivity to oxaliplatin in colorectal cancer cells. Proteome Sci. 2014, 12, 26. [CrossRef] [PubMed]

52. Okuse, K.; Malik-Hall, M.; Baker, M.D.; Poon, W.Y.; Kong, H.; Chao, M.V.; Wood, J.N. Annexin II light chain regulates sensory neuron-specific sodium channel expression. Nature 2002, 417, 653-656. [CrossRef] [PubMed]

53. Girard, C.; Tinel, N.; Terrenoire, C.; Romey, G.; Lazdunski, M.; Borsotto, M. p11, an annexin II subunit, an auxiliary protein associated with the background K+ channel, TASK-1. EMBO J. 2002, 21, 4439-4448. [CrossRef] [PubMed] 
54. van de Graaf, S.F.; Hoenderop, J.G.; Gkika, D.; Lamers, D.; Prenen, J.; Rescher, U.; Gerke, V.; Staub, O.; Nilius, B.; Bindels, R.J. Functional expression of the epithelial $\mathrm{Ca}^{2+}$ channels (TRPV5 and TRPV6) requires association of the S100A10-annexin 2 complex. EMBO J. 2003, 22, 1478-1487. [CrossRef] [PubMed]

55. Donier, E.; Rugiero, F.; Okuse, K.; Wood, J.N. Annexin II light chain p11 promotes functional expression of acid-sensing ion channel ASIC1a. J. Biol. Chem. 2005, 280, 38666-38672. [CrossRef]

56. Svenningsson, P.; Chergui, K.; Rachleff, I.; Flajolet, M.; Zhang, X.; El Yacoubi, M.; Vaugeois, J.M.; Nomikos, G.G.; Greengard, P. Alterations in 5-HT1B receptor function by p11 in depression-like states. Science 2006, 311, 77-80. [CrossRef] [PubMed]

57. Rezvanpour, A.; Santamaria-Kisiel, L.; Shaw, G.S. The S100A10-annexin A2 complex provides a novel asymmetric platform for membrane repair. J. Biol. Chem. 2011, 286, 40174-40183. [CrossRef] [PubMed]

58. Ozorowski, G.; Milton, S.; Luecke, H. Structure of a C-terminal AHNAK peptide in a 1:2:2 complex with S100A10 and an acetylated N-terminal peptide of annexin A2. Acta Crystallogr. D Biol. Crystallogr. 2013, 69, 92-104. [CrossRef]

59. Oh, Y.S.; Gao, P.; Lee, K.W.; Ceglia, I.; Seo, J.S.; Zhang, X.; Ahn, J.H.; Chait, B.T.; Patel, D.J.; Kim, Y.; et al. SMARCA3, a chromatin-remodeling factor, is required for p11-dependent antidepressant action. Cell 2013, 152, 831-843. [CrossRef] [PubMed]

60. Sayeed, S.; Asano, E.; Ito, S.; Ohno, K.; Hamaguchi, M.; Senga, T. S100A10 is required for the organization of actin stress fibers and promotion of cell spreading. Mol. Cell. Biochem. 2013, 374, 105-111. [CrossRef] [PubMed]

61. Degos, L.; Wang, Z.Y. All trans retinoic acid in acute promyelocytic leukemia. Oncogene 2001, 20, 7140-7145. [CrossRef] [PubMed]

62. Menell, J.S.; Cesarman, G.M.; Jacovina, A.T.; McLaughlin, M.A.; Lev, E.A.; Hajjar, K.A. Annexin II and bleeding in acute promyelocytic leukemia. N. Engl. J. Med. 1999, 340, 994-1004. [CrossRef] [PubMed]

63. Huang, D.; Yang, Y.; Sun, J.; Dong, X.; Wang, J.; Liu, H.; Lu, C.; Chen, X.; Shao, J.; Yan, J. Annexin A2-S100A10 heterotetramer is upregulated by PML/RARalpha fusion protein and promotes plasminogen-dependent fibrinolysis and matrix invasion in acute promyelocytic leukemia. Front. Med. 2017, 11, 410-422. [CrossRef] [PubMed]

64. Gopalakrishnapillai, A.; Kolb, E.A.; Dhanan, P.; Mason, R.W.; Napper, A.; Barwe, S.P. Disruption of Annexin II /p11 Interaction Suppresses Leukemia Cell Binding, Homing and Engraftment, and Sensitizes the Leukemia Cells to Chemotherapy. PLoS ONE 2015, 10, e0140564. [CrossRef] [PubMed]

65. Zhang, Q.; Zhu, M.; Cheng, W.; Xing, R.; Li, W.; Zhao, M.; Xu, L.; Li, E.; Luo, G.; Lu, Y. Downregulation of $425 \mathrm{G}>$ a variant of calcium-binding protein S100A14 associated with poor differentiation and prognosis in gastric cancer. J. Cancer Res. Clin. Oncol. 2015, 141, 691-703. [CrossRef] [PubMed]

66. Liu, G.; Fei, F.; Qu, J.; Wang, X.; Zhao, Y.; Li, Y.; Zhang, S. iTRAQ-based proteomic analysis of DMH-induced colorectal cancer in mice reveals the expressions of beta-catenin, decorin, septin-7, and S100A10 expression in 53 cases of human hereditary polyposis colorectal cancer. Clin. Transl. Oncol. 2018. [CrossRef]

67. Li, C.M.; Hou, Y.H.; Zhang, J.; Zhang, L. The expressions and roles of S100A6 and S100A10 in gastric cancer. Biomed. Res. India 2017, 28, 2131-2138.

68. Rust, R.; Visser, L.; van der Leij, J.; Harms, G.; Blokzijl, T.; Deloulme, J.C.; van der Vlies, P.; Kamps, W.; Kok, K.; Lim, M.; et al. High expression of calcium-binding proteins, S100A10, S100A11 and CALM2 in anaplastic large cell lymphoma. Br. J. Haematol. 2005, 131, 596-608. [CrossRef] [PubMed]

69. Tingfeng, X.; Fuqiang, P.; Dong, L. Expression and clinical significance of S100 family genes in patients with melanoma. Melanoma Res. 2018. [CrossRef]

70. McKiernan, E.; McDermott, E.W.; Evoy, D.; Crown, J.; Duffy, M.J. The role of S100 genes in breast cancer progression. Tumour Biol. 2011, 32, 441-450. [CrossRef] [PubMed]

71. Domoto, T.; Miyama, Y.; Suzuki, H.; Teratani, T.; Arai, K.; Sugiyama, T.; Takayama, T.; Mugiya, S.; Ozono, S.; Nozawa, R. Evaluation of S100A10, annexin II and B-FABP expression as markers for renal cell carcinoma. Cancer Sci. 2007, 98, 77-82. [CrossRef] [PubMed]

72. Teratani, T.; Watanabe, T.; Kuwahara, F.; Kumagai, H.; Kobayashi, S.; Aoki, U.; Ishikawa, A.; Arai, K.; Nozawa, R. Induced transcriptional expression of calcium-binding protein S100A1 and S100A10 genes in human renal cell carcinoma. Cancer Lett. 2002, 175, 71-77. [CrossRef] 
73. El-Rifai, W.; Moskaluk, C.A.; Abdrabbo, M.K.; Harper, J.; Yoshida, C.; Riggins, G.J.; Frierson, H.F., Jr.; Powell, S.M. Gastric cancers overexpress S100A calcium-binding proteins. Cancer Res. 2002, 62, 6823-6826. [PubMed]

74. Chetcuti, A.; Margan, S.H.; Russell, P.; Mann, S.; Millar, D.S.; Clark, S.J.; Rogers, J.; Handelsman, D.J.; Dong, Q. Loss of annexin II heavy and light chains in prostate cancer and its precursors. Cancer Res. 2001, 61, 6331-6334. [PubMed]

75. Martinez-Aguilar, J.; Clifton-Bligh, R.; Molloy, M.P. A multiplexed, targeted mass spectrometry assay of the S100 protein family uncovers the isoform-specific expression in thyroid tumours. BMC Cancer 2015, 15, 199. [CrossRef]

76. Ito, Y.; Arai, K.; Nozawa, R.; Yoshida, H.; Higashiyama, T.; Takamura, Y.; Miya, A.; Kobayashi, K.; Kuma, K.; Miyauchi, A. S100A10 expression in thyroid neoplasms originating from the follicular epithelium: Contribution to the aggressive characteristic of anaplastic carcinoma. Anticancer Res. 2007, 27, 2679-2683.

77. Tan, Y.; Ma, S.Y.; Wang, F.Q.; Meng, H.P.; Mei, C.Z.; Liu, A.G.; Wu, H.R. Proteomic-based analysis for identification of potential serum biomarkers in gallbladder cancer. Oncol. Rep. 2011, 26, 853-859.

78. Sato, K.; Saiki, Y.; Arai, K.; Ishizawa, K.; Fukushige, S.; Aoki, K.; Abe, J.; Takahashi, S.; Sato, I.; Sakurada, A.; et al. S100A10 upregulation associates with poor prognosis in lung squamous cell carcinoma. Biochem. Biophys. Res. Commun. 2018, 505, 466-470. [CrossRef]

79. Katono, K.; Sato, Y.; Jiang, S.X.; Kobayashi, M.; Saito, K.; Nagashio, R.; Ryuge, S.; Satoh, Y.; Saegusa, M.; Masuda, N. Clinicopathological Significance of S100A10 Expression in Lung Adenocarcinomas. Asian Pac. J. Cancer Prev. 2016, 17, 289-294. [CrossRef]

80. Bydoun, M.; Sterea, A.; Liptay, H.; Uzans, A.; Huang, W.Y.; Rodrigues, G.J.; Weaver, I.C.G.; Gu, H.; Waisman, D.M. S100A10, a novel biomarker in pancreatic ductal adenocarcinoma. Mol. Oncol. 2018, 12, 1895-1916. [CrossRef]

81. Gocheva, V.; Naba, A.; Bhutkar, A.; Guardia, T.; Miller, K.M.; Li, C.M.; Dayton, T.L.; Sanchez-Rivera, F.J.; Kim-Kiselak, C.; Jailkhani, N.; et al. Quantitative proteomics identify Tenascin-C as a promoter of lung cancer progression and contributor to a signature prognostic of patient survival. Proc. Natl. Acad. Sci. USA 2017, 114, E5625-E5634. [CrossRef] [PubMed]

82. Shang, J.; Zhang, Z.; Song, W.; Zhou, B.; Zhang, Y.; Li, G.; Qiu, S. S100A10 as a novel biomarker in colorectal cancer. Tumour Biol. 2013, 34, 3785-3790. [CrossRef] [PubMed]

83. Giraldez, M.D.; Lozano, J.J.; Cuatrecasas, M.; Alonso-Espinaco, V.; Maurel, J.; Marmol, M.; Horndler, C.; Ortego, J.; Alonso, V.; Escudero, P.; et al. Gene-expression signature of tumor recurrence in patients with stage II and III colon cancer treated with 5'fluoruracil-based adjuvant chemotherapy. Int. J. Cancer 2013, 132, 1090-1097. [CrossRef] [PubMed]

84. Liu, Y.; Cui, J.; Tang, Y.L.; Huang, L.; Zhou, C.Y.; Xu, J.X. Prognostic Roles of mRNA Expression of S100 in Non-Small-Cell Lung Cancer. BioMed Res. Int. 2018, 2018, 9815806. [CrossRef] [PubMed]

85. Hatoum, D.; Yagoub, D.; Ahadi, A.; Nassif, N.T.; McGowan, E.M. Annexin/S100A Protein Family Regulation through p14ARF-p53 Activation: A Role in Cell Survival and Predicting Treatment Outcomes in Breast Cancer. PLoS ONE 2017, 12, e0169925. [CrossRef] [PubMed]

86. Phipps, K.D.; Surette, A.P.; O'Connell, P.A.; Waisman, D.M. Plasminogen receptor S100A10 is essential for the migration of tumor-promoting macrophages into tumor sites. Cancer Res. 2011, 71, 6676-6683. [CrossRef]

87. Yang, X.; Popescu, N.C.; Zimonjic, D.B. DLC1 interaction with S100A10 mediates inhibition of in vitro cell invasion and tumorigenicity of lung cancer cells through a RhoGAP-independent mechanism. Cancer Res. 2011, 71, 2916-2925. [CrossRef]

88. Shan, X.; Miao, Y.; Fan, R.; Qian, H.; Chen, P.; Liu, H.; Yan, X.; Li, J.; Zhou, F. MiR-590-5P inhibits growth of HepG2 cells via decrease of S100A10 expression and Inhibition of the Wnt pathway. Int. J. Mol. Sci. 2013, 14, 8556-8569. [CrossRef]

89. D’Souza, S.; Kurihara, N.; Shiozawa, Y.; Joseph, J.; Taichman, R.; Galson, D.L.; Roodman, G.D. Annexin II interactions with the annexin II receptor enhance multiple myeloma cell adhesion and growth in the bone marrow microenvironment. Blood 2012, 119, 1888-1896. [CrossRef]

90. Shiozawa, Y.; Havens, A.M.; Jung, Y.; Ziegler, A.M.; Pedersen, E.A.; Wang, J.; Wang, J.; Lu, G.; Roodman, G.D.; Loberg, R.D.; et al. Annexin II/annexin II receptor axis regulates adhesion, migration, homing, and growth of prostate cancer. J. Cell. Biochem. 2008, 105, 370-380. [CrossRef] 
91. Myrvang, H.K.; Guo, X.; Li, C.; Dekker, L.V. Protein interactions between surface annexin A2 and S100A10 mediate adhesion of breast cancer cells to microvascular endothelial cells. FEBS Lett. 2013, 587, 3210-3215. [CrossRef] [PubMed]

92. Zhang, L.; Fogg, D.K.; Waisman, D.M. RNA interference-mediated silencing of the S100A10 gene attenuates plasmin generation and invasiveness of Colo 222 colorectal cancer cells. J. Biol. Chem. 2004, 279, 2053-2062. [CrossRef] [PubMed]

93. Choi, K.S.; Fogg, D.K.; Yoon, C.S.; Waisman, D.M. p11 regulates extracellular plasmin production and invasiveness of HT1080 fibrosarcoma cells. FASEB J. 2003, 17, 235-246. [CrossRef] [PubMed]

94. Madureira, P.A.; Bharadwaj, A.G.; Bydoun, M.; Garant, K.; O'Connell, P.; Lee, P.; Waisman, D.M. Cell surface protease activation during RAS transformation: Critical role of the plasminogen receptor, S100A10. Oncotarget 2016, 7, 47720-47737. [CrossRef] [PubMed]

95. Yu, M.; Bardia, A.; Wittner, B.S.; Stott, S.L.; Smas, M.E.; Ting, D.T.; Isakoff, S.J.; Ciciliano, J.C.; Wells, M.N.; Shah, A.M.; et al. Circulating breast tumor cells exhibit dynamic changes in epithelial and mesenchymal composition. Science 2013, 339, 580-584. [CrossRef]

96. Spijkers-Hagelstein, J.A.; Mimoso Pinhancos, S.; Schneider, P.; Pieters, R.; Stam, R.W. Src kinase-induced phosphorylation of annexin A2 mediates glucocorticoid resistance in MLL-rearranged infant acute lymphoblastic leukemia. Leukemia 2013, 27, 1063-1071. [CrossRef]

97. Browne, B.C.; Hochgrafe, F.; Wu, J.; Millar, E.K.; Barraclough, J.; Stone, A.; McCloy, R.A.; Lee, C.S.; Roberts, C.; Ali, N.A.; et al. Global characterization of signalling networks associated with tamoxifen resistance in breast cancer. FEBS J. 2013, 280, 5237-5257. [CrossRef]

98. Johansson, H.J.; Sanchez, B.C.; Forshed, J.; Stal, O.; Fohlin, H.; Lewensohn, R.; Hall, P.; Bergh, J.; Lehtio, J.; Linderholm, B.K. Proteomics profiling identify CAPS as a potential predictive marker of tamoxifen resistance in estrogen receptor positive breast cancer. Clin. Proteom. 2015, 12, 8. [CrossRef]

99. Hsu, S.Y.; Kaipia, A.; Zhu, L.; Hsueh, A.J. Interference of BAD (Bcl-xL/Bcl-2-associated death promoter)-induced apoptosis in mammalian cells by 14-3-3 isoforms and P11. Mol. Endocrinol. 1997, 11, 1858-1867.

100. Gillet, J.P.; Calcagno, A.M.; Varma, S.; Davidson, B.; Bunkholt Elstrand, M.; Ganapathi, R.; Kamat, A.A.; Sood, A.K.; Ambudkar, S.V.; Seiden, M.V.; et al. Multidrug resistance-linked gene signature predicts overall survival of patients with primary ovarian serous carcinoma. Clin. Cancer Res. 2012, 18, 3197-3206. [CrossRef]

101. Li, C.; Reddy, T.R.; Fischer, P.M.; Dekker, L.V. A Cy5-labeled S100A10 tracer used to identify inhibitors of the protein interaction with annexin A2. Assay Drug Dev. Technol. 2010, 8, 85-95. [CrossRef] [PubMed]

102. Reddy, T.R.; Li, C.; Guo, X.; Myrvang, H.K.; Fischer, P.M.; Dekker, L.V. Design, synthesis, and structure-activity relationship exploration of 1-substituted 4-aroyl-3-hydroxy-5-phenyl-1H-pyrrol-2(5H)-one analogues as inhibitors of the annexin A2-S100A10 protein interaction. J. Med. Chem. 2011, 54, 2080-2094. [CrossRef] [PubMed]

103. Reddy, T.R.; Li, C.; Fischer, P.M.; Dekker, L.V. Three-dimensional pharmacophore design and biochemical screening identifies substituted 1,2,4-triazoles as inhibitors of the annexin A2-S100A10 protein interaction. ChemMedChem 2012, 7, 1435-1446. [CrossRef] [PubMed]

104. Reddy, T.R.; Li, C.; Guo, X.; Fischer, P.M.; Dekker, L.V. Design, synthesis and SAR exploration of tri-substituted 1,2,4-triazoles as inhibitors of the annexin A2-S100A10 protein interaction. Bioorg. Med. Chem. 2014, 22, 5378-5391. [CrossRef]

105. Lo-Coco, F.; Avvisati, G.; Vignetti, M.; Thiede, C.; Orlando, S.M.; Iacobelli, S.; Ferrara, F.; Fazi, P.; Cicconi, L.; Di Bona, E.; et al. Retinoic acid and arsenic trioxide for acute promyelocytic leukemia. N. Engl. J. Med. 2013, 369, 111-121. [CrossRef]

106. Olwill, S.A.; McGlynn, H.; Gilmore, W.S.; Alexander, H.D. All-trans retinoic acid-induced downregulation of annexin II expression in myeloid leukaemia cell lines is not confined to acute promyelocytic leukaemia. Br. J. Haematol. 2005, 131, 258-264. [CrossRef]

107. Olwill, S.A.; McGlynn, H.; Gilmore, W.S.; Alexander, H.D. Annexin II cell surface and mRNA expression in human acute myeloid leukaemia cell lines. Thromb. Res. 2005, 115, 109-114. [CrossRef]

108. Zhang, X.; Zhou, H.; Wang, J.; Yang, L.; Hu, Y.; Shen, G.; Guo, P.; Qiao, Z.; Song, S. Arsenic trioxide, retinoic acid and Ara-c regulated the expression of annexin II on the surface of APL cells, a novel co-receptor for plasminogen/tissue plasminogen activator. Thromb. Res. 2002, 106, 63-70. [CrossRef] 
109. Liu, Y.; Wang, Z.; Jiang, M.; Dai, L.; Zhang, W.; Wu, D.; Ruan, C. The expression of annexin II and its role in the fibrinolytic activity in acute promyelocytic leukemia. Leuk. Res. 2011, 35, 879-884. [CrossRef]

110. Gladwin, M.T.; Yao, X.L.; Cowan, M.; Huang, X.L.; Schneider, R.; Grant, L.R.; Logun, C.; Shelhamer, J.H. Retinoic acid reduces $\mathrm{p} 11$ protein levels in bronchial epithelial cells by a posttranslational mechanism. Am. J. Physiol. Lung Cell. Mol. Physiol. 2000, 279, L1103-L1109. [CrossRef]

111. Holloway, R.W.; Thomas, M.L.; Cohen, A.M.; Bharadwaj, A.G.; Rahman, M.; Marcato, P.; Marignani, P.A.; Waisman, D.M. Regulation of cell surface protease receptor S100A10 by retinoic acid therapy in acute promyelocytic leukemia (APL). Cell Death Dis. 2018, 9, 920. [CrossRef] [PubMed]

112. Purev, E.; Soprano, D.R.; Soprano, K.J. PP2A interaction with Rb2/p130 mediates translocation of Rb2/p130 into the nucleus in all-trans retinoic acid-treated ovarian carcinoma cells. J. Cell. Physiol. 2011, 226, 1027-1034. [CrossRef] [PubMed]

113. Ricciardelli, C.; Lokman, N.A.; Sabit, I.; Gunasegaran, K.; Bonner, W.M.; Pyragius, C.E.; Macpherson, A.M.; Oehler, M.K. Novel ex vivo ovarian cancer tissue explant assay for prediction of chemosensitivity and response to novel therapeutics. Cancer Lett. 2018, 421, 51-58. [CrossRef] [PubMed]

114. Escudier, S.M.; Kantarjian, H.M.; Estey, E.H. Thrombosis in patients with acute promyelocytic leukemia treated with and without all-trans retinoic acid. Leuk. Lymphoma 1996, 20, 435-439. [CrossRef] [PubMed]

115. de-Medeiros, B.C.; Strapasson, E.; Pasquini, R.; de-Medeiros, C.R. Effect of all-trans retinoic acid on newly diagnosed acute promyelocytic leukemia patients: Results of a Brazilian center. Braz. J. Med. Biol. Res. 1998, 31, 1537-1543. [CrossRef] [PubMed]

116. Mandelli, F.; Diverio, D.; Avvisati, G.; Luciano, A.; Barbui, T.; Bernasconi, C.; Broccia, G.; Cerri, R.; Falda, M.; Fioritoni, G.; et al. Molecular remission in PML/RAR alpha-positive acute promyelocytic leukemia by combined all-trans retinoic acid and idarubicin (AIDA) therapy. Gruppo Italiano-Malattie Ematologiche Maligne dell'Adulto and Associazione Italiana di Ematologia ed Oncologia Pediatrica Cooperative Groups. Blood 1997, 90, 1014-1021. [PubMed]

117. Tallman, M.S.; Andersen, J.W.; Schiffer, C.A.; Appelbaum, F.R.; Feusner, J.H.; Ogden, A.; Shepherd, L.; Willman, C.; Bloomfield, C.D.; Rowe, J.M.; et al. All-trans-retinoic acid in acute promyelocytic leukemia. N. Engl. J. Med. 1997, 337, 1021-1028. [CrossRef]

118. De Stefano, V.; Sora, F.; Rossi, E.; Chiusolo, P.; Laurenti, L.; Fianchi, L.; Zini, G.; Pagano, L.; Sica, S.; Leone, G. The risk of thrombosis in patients with acute leukemia: Occurrence of thrombosis at diagnosis and during treatment. J. Thromb. Haemost. 2005, 3, 1985-1992. [CrossRef] [PubMed] 